\title{
Cenozoic decapod crustacean assemblages from northeast Japan
}

\author{
Hisayoshi Kato \\ Natural History Museum and Institute, Chiba 955-2, Aoba-cho, Cuba 260-8682, Japan
}

Keywords: Cenozoic, decapod crustaceans, molluscan fauna, northeast Japan

\begin{abstract}
Decapod crustacean faunas from the Cenozoic of NE Japan are discussed and summarized in relation to marine climates and molluscan faunas.
\end{abstract}

\section{Introduction}

The study area is the whole of northeastern Japan, as delimited by the Fossa Magna, a major tectonic line that splits the Japanese main islands into a southwest and northeast part geologically (Fig. 1). The fossil crustaceans of this area are quite varied and have heretofore not received the attention they deserve

\section{Results}

In the Paleogene fauna, there are no species in common with SW Japan. Even at the generic level, there are almost no common elements to SW Japanese faunas. The decapod fauna of the Upper Eocene to Lower Oligocene of Hokkaido is rather related to that from the Pacific coast of North America (Kato, 1999; Schweitzer, 2001). Typical Tethyan elements are rarely observed in the Paleogene of NE Japan; this in contrast to SW Japan (Karasawa, 1999).

Although the Early Miocene decapod fauna in NE Japan is represented by few localities, the numbers of specimens are not small owing to an abundant occurrence of the grapsid, Miosesarma japonicum Karasawa. Considering that Miosesarma occurs in association with subtropical or warm-water molluscan assemblages, and in view of abundant records from SW Japan (Karasawa, 1990, 1993; Sakumoto, 1997), $M$. japonicum apparently had a southerly origin and seems to have migrated into NE Japan by way of warm-water currents in the late Early Miocene times.

The most diversified decapod assemblages in the Cenozoic of Japan are recognized in lower Middle Miocene rocks. At least fifteen decapod assemblages have been recorded, based on dominant species and other components. The reason of this high diversity is not only the extensive distribution of fossiliferous marine strata deposited in various environments but also the warm marine climate of the Pacific region in this period, the so-called 'the Mid Neogene Climatic Optimum,' e.g., Tsuchi $(1990,1992)$. Karasawa $(1993,1997,1999)$ discussed the relationships between the warm-water species in the Neogene decapod faunal succession in SW Japan and warm marine climatic events proposed by Barron \& Baldauf (1990) and Tsuchi (1990). Among the Neogene warm phases proposed as three 'climatic optima' and one 'warm episode', the climatic optimum 1, termed 'the Mid Neogene climatic optimum' has been recognized as the molluscan Kadonosawa Fauna (e.g. Chinzei, 1978, 1981) or the tropical spike (Itoigawa, 1989) in lower Middle Miocene strata. In SW Japan, the decapod fauna of this time interval is the most diversified in the whole Cenozoic and for the whole of SW Japan, and contains genera indicative of subtropical to tropical environments, i.e., Thalassina, Ozius, Glabropilum- 


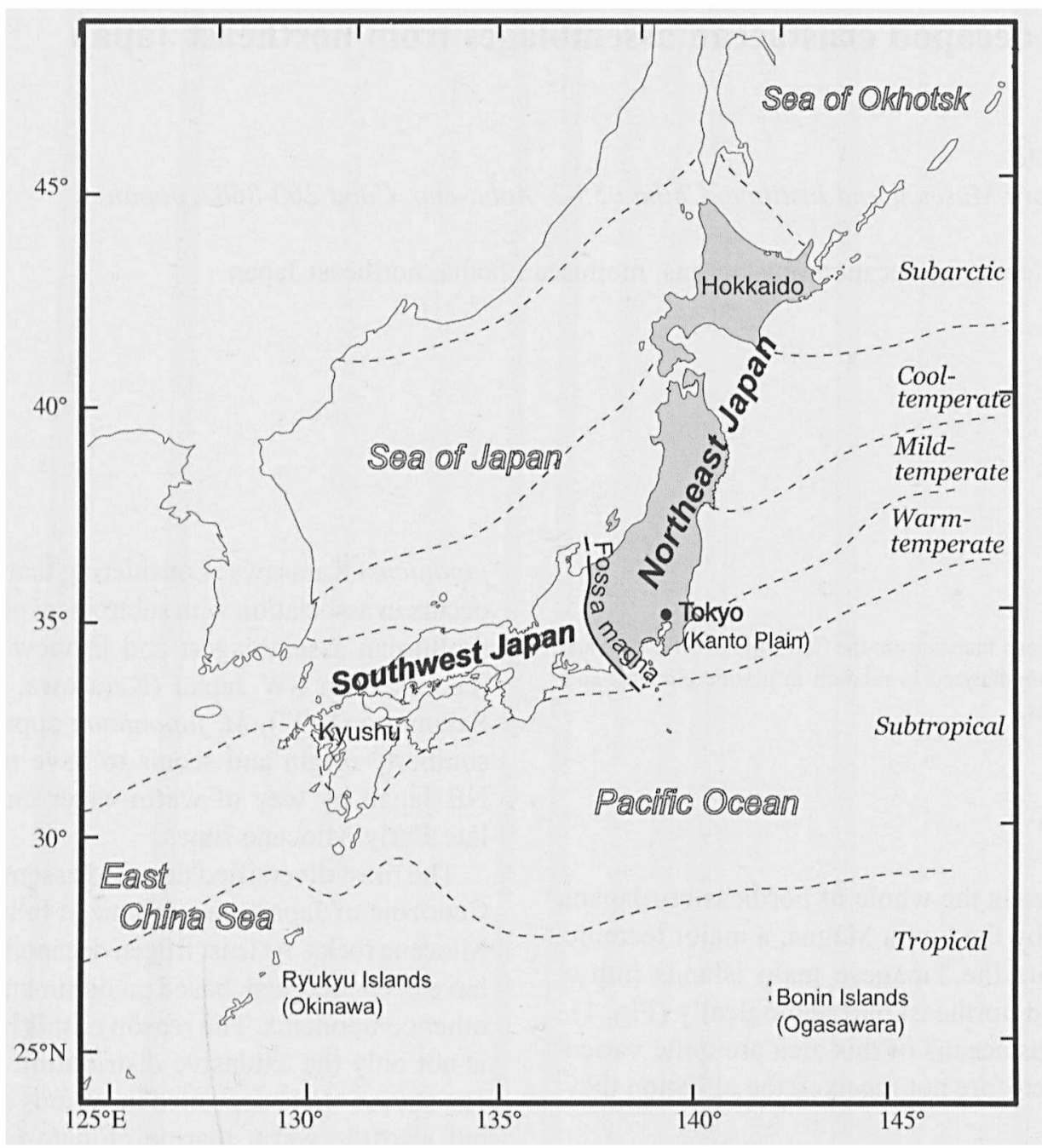

Fig. I. Map showing the study area and the marine zoogeographic divisions of the Recent Japanese waters (after Ogasawara, 1994).

nus, Typilobus, Daira, Euryozius, in addition to the warm Indo-Pacific or Tethyan element. Despite the distribution of molluscan assemblages indicative of subtropical environments in the southern part of NE Japan, however, such typical tropical to subtropical decapod species were not found.

After the middle Middle Miocene, occurrences of decapod crustacean fossils decrease so that it is difficult to define decapod assemblages. Nevertheless, the tendency in late Middle to Late Miocene decapod faunas is repetitious occurrences of Cancer (Metacarcinus) spp. and Hyas spp. These are usually obtained in association with cold-water type molluscan fauna, the Shiobara-Yama Fauna (Chinzei, 1963; Iwasaki, 1970, 1981). In SW Japan, Kara- sawa $(1993,1997,1999)$ concluded that the decapod fauna from the Middle Miocene Kukinaga Group and the Late Miocene-Pliocene Miyazaki Group correspond to climatic optimum 2 and 3, respectively. With regard to the latter, the subtropical to tropical genus Daldorfia was observed also in Upper Miocene of the Pacific coast of NE Japan (Kato, 2002). This taxon suggests subtropical marine climate that may corresponds to the molluscan Zushi Fauna (Ozawa \& Tomida, 1992; Ozawa et al., 1995) and climatic optimum 3. However, a decapod fauna indicative of former warm marine climates was not recognized in the late Middle Miocene of NE Japan.

The latest Miocene to Early Pliocene decapod 
Table 1. Numbers of species and genera, those common to both NE and SW Japan, and those of extant species at various stratigraphic ages.

\begin{tabular}{lccccc}
\hline Stratigraphic age & $\begin{array}{l}\text { northeast } \\
\text { Japan }\end{array}$ & $\begin{array}{l}\text { southwest } \\
\text { Japan }\end{array}$ & $\begin{array}{l}\text { Common } \\
\text { sp. and gen. }\end{array}$ & Total & $\begin{array}{c}\text { Identified } \\
\text { living sp. and gen. }\end{array}$ \\
\hline Late Pleistocene & $60 / 49$ & $24 / 20$ & $3 / 10$ & $81 / 59$ & $47 / 59$ \\
Míddle Pleistocene & $16 / 15$ & $48 / 34$ & $3 / 8$ & $61 / 41$ & $30 / 41$ \\
Early Pleistocene & $7 / 6$ & $4 / 3$ & $2 / 2$ & $9 / 7$ & $5 / 7$ \\
Late Pliocene & $5 / 3$ & $24 / 21$ & $0 / 2$ & $29 / 22$ & $10 / 22$ \\
Early Pliocene & $7 / 6$ & $10 / 10$ & $0 / 0$ & $17 / 16$ & $2 / 16$ \\
Late Miocene & $12 / 8$ & $6 / 5$ & $0 / 1$ & $18 / 12$ & $1 / 12$ \\
Late Middle Miocene & $3 / 3$ & $7 / 6$ & $0 / 0$ & $10 / 9$ & $1 / 10$ \\
Middle Middle Miocene & $3 / 3$ & $16 / 12$ & $2 / 2$ & $17 / 13$ & $0 / 17$ \\
Early Middle Miocene & $35 / 23$ & $56 / 47$ & $11 / 13$ & $80 / 57$ & $2 / 52$ \\
Early Miocene & $12 / 11$ & $29 / 24$ & $5 / 9$ & $36 / 26$ & $0 / 23$ \\
Late Oligocene & - & $2 / 2$ & - & $2 / 2$ & $0 / 1$ \\
Early Oligocene & $1 / 1$ & $9 / 8$ & $0 / 0$ & $10 / 9$ & $0 / 4$ \\
Late Eocene & $5 / 5$ & - & - & $5 / 5$ & $0 / 2$ \\
Middle Eocene & $7 / 6$ & $7 / 7$ & $0 / 1$ & $14 / 12$ & $0 / 3$ \\
\hline
\end{tabular}

number of species / number of genera

fauna is still characterized by the abundance of Cancer (Metacarcinus) spp. and Hyas spp. throughout. Whereas no descendant of the former lives in the NW Pacific, the fossil record of the latter is in accord with the distribution of the extant species in Recent Japanese waters, viz, obtained from the Sea of Japan side. On the other hand, occurrences of decapod species indicative of a warm marine environment are quite few in the northern part of NE Japan, in post-Late Miocene time. Considering these facts, the recent cold-water decapod fauna of northern Japan seems to have originated during the Late Miocene to Early Pliocene.

The Late Pliocene decapod fauna is represented by relatively limited horizons. However, the decapod fossils from the Kanzawa Formation, Nakatsu Group, Kanto Plain occur in association with molluscan fossils indicating a warm environment, the 'Kakegawa Fauna' (Masuda \& Ogasawara, 1981), which is a molluscan fauna correlative to the warm episode in Tsuchi (1990, 1992). Karasawa (1993) recognized three decapod assemblages in the Upper Pliocene to Lower Pleistocene of the Kakegawa Group, central Japan. However, none was observed in NE Japan. The decapod fauna associated with the Kakegawa molluscan fauna seems to be characterized by the oldest records of several extant species rather than containing warm-water species (Karasawa, 1997).

The diverse Pleistocene decapod faunas in NE
Japan are observed in thick, exhaustively investigated Pleistocene strata in the Kanto Plain. These decapod-bearing strata were deposited in various environments. Since the depositional environments of these decapod-bearing horizons are mostly different from those of SW Japan, the number of the species in common to that area is not large (Table 1). The vast majority of taxa are assignable to extant species, but three are noteworthy extinct species, Cancer (Metacarcinus)'n. sp., Chaceon matsushimai Kato \& Koizumi and Grynaminna grandis (Karasawa \& Goda), recognized in the Pleistocene of NE Japan. Cancer (Metacarcinus) n. sp. from the Lower Pleistocene of the Kanto Plain is the latest record of the subgenus in the NW Pacific. In the Middle to Upper Pleistocene of NE Japan, all taxa identified at the species level are assigned to extant ones, except for Grynaminna grandis. While this species is the most dominant decapod element in the Middle to Upper Pleistocene of Japan, the only congener, G. tamakii Poore, is known only from a quite restricted area in Kyushu, SW Japan, as a relict (Poore, 2000).

\section{Conclusion}

On the whole, decapod species indicative of subtropical to tropical marine climates in the Cenozoic of NE Japan are evidently fewer than those in 
SW Japan, so that the optimal events recognized in the decapod fauna are not as clear as those there. In contrast, cold-water elements are clearly recognized in the Middle Miocene to Lower Pliocene of NE Japan.

\section{References}

Barron JA, Baldauf JG. 1990. Development of biosiliceous sedimentation in the North Pacific during the Miocene and Early Pliocene. In: Tsuchî R (ed.). Pacific Neogene Event, their Timing, Nature and Interrelationship, 43-64. Shizuoka.

Chinzei K. 1978. Neogene molluscan faunas in the Japanese Islands: an ecologic and zoogeographic synthesis. Veliger 21: 155-170.

Chinzel K, 1981. The Kadonosawa Fauna, In: Study of Molluscan Paleobiology (Prof. M. Omori Memorial Volume), 207-212 (in Japanese).

Itoigawa J. 1989. Tropical spike in early middle Miocene (ca. $16 \mathrm{Ma}$ ) of southwest Japan. In: Gengure L. et al. (eds). Proc. Internatl. Symp. Pacific Neogene Continental and Marine Events: 19-26. Nanjing.

Karasawa H. 1990. [Miocene Decapod Crustacean Assemblages from Southwest Japan. With Special Reference to the Intertidal Assemblages of Muddy Bottom]. Monogr. Mizunami Fossil Mus. 7: 101-116 (in Japanese).

Karasawa H. 1993. Cenozoic decapod Crustacea from southwest Japan. Bull. Mizunami Fossil Mus. 20: 1-92.

Karasawa H. 1997. [A monograph of Cenozoic stomatopod, decapod Isopod and amphipod Crustacea from West Japan]. Monogr. Mizunami Fossil Mus. 8: 1-81 (in Japanese).

Karasawa H. 1999. The Cenozoic decapod crustacean fauna of southwest Japan. Proc. Fourth Internatl. Crust. Cong. 1998: 29-44.
Kato H. 1999. Paleogene decapod fauna from northeast Japan. Studi e Ricerche, Assoc. Amici Museo civ. 'G. Zannato', Montecchio Maggiore (Vicenza): 47-48.

Kato H. 2002. Fossil crabs (Crustacea: Decapoda: Brachyura) from the latest Miocene Senhata Formation, Boso Peninsula, Japan. Paleont. Res. 6: 211-217.

Masuda K, Ogasawara K. 1981. [On the Omma-Manganzi Fauna and Tatsunokuchi Fauna]. In: Study of Molluscan Paleobiology (Prof. M. Omori Memorial Volume), 223249 (in Japanese).

Ogasawara K. 1994. Neogene paleogeography and marine climate of the Japanese Islands based on shallow-marine molluses. Palaeogeogr, Palaeoclimatol., Palaeoecol. 108: 335-351.

Ozawa T, Tomida S. 1992. [The Zushi Fauna - Late Miocene-Early Pliocene warm marine water molluscan fauna of Japan]. Bull. Mizunami Fossil Mus, 19:; 427-439 (in Japanese).

Ozawa $\mathbf{T}$, Inoue $\mathrm{K}$, Tomida $\mathrm{S}$, Tanaka $\mathrm{T}$, Nobuhara $\mathbf{T}$. 1995. [An outline of the Neogene warm water molluscan faunas in Japan]. Kaseki 58: 20-27 (in Japanese).

Poore GCB. 2000. A new genus and species of callianassid ghost shrimp from Kyushu, Japan (Decapoda: Thalassinidea). $J$. crust. Biol. 20 (Spec. No. 2): 150-156.

Sakumoto T. 1997. [Decapod crustacean assemblages from the Miocene Bihoku Group in the Shobara area, Hiroshima Prefecture, southwest Japan]. Cikyu Kagaku 51: 146-157 (in Japanese).

Schweitzer CE. 2001. Paleobiogeography of Cretaceous and Tertiary decapod crustaceans of the north Pacific Ocean. Jour. Paleont. 75: 808-826.

Tsuchi R. 1990. Neogene events in Japan and Pacific. Palaeogeogr., Palaeoclimatol., Palaeoecol. 77* 355-365.

Tsuchi R. 1992. Pacific Neogene climatic optimum and accelerated biotic evolution in time and space. In: Tsuchi R, Ingle JC Jr. (eds). Pacific Neogenex 237-250, Tokyo: University of Tokyo Press.

Received: 1 April 2003 